\title{
Avaliação da Interferometria de Radar (InSAR) para o Monitoramento de Atividades Garimpeiras na Área de Peixoto de Azevedo (MT).
}

\section{Brenda G. C Feitosa *, Diego F Ducart.}

\section{Resumo}

O município Peixoto de Azevedo localizado ao norte do estado Mato Grosso, concentra intensas atividades garimpeiras desde a década de $80 \mathrm{e}$, atualmente, essa continua sendo uma atividade significativa para economia local. O longo período de garimpagem trouxe graves problemas ambientais para região: processos erosivos concentrados no solo, como voçorocas e ravinas; assoreamento do rio; desmatamento da mata ciliar e outros. Antes de qualquer medida visando recuperação é necessário entender e avaliar o impacto ambiental atual através de um diagnóstico das áreas já degradadas. Sendo este o principal objetivo deste projeto, aplicará-se a técnica de interferometria por radar de abertura sintética (InSAR) para registrar de forma precisa mudanças sutis na superfície provocadas pelas atividades garimpeiras na região Peixoto de Azevedo. As imagens serão obtidas do sensor radar Sentinel-1 e processadas no software SNAP (ESA) e IPC para aplicar a técnica de interferometria. Dessa forma, o objetivo secundário deste projeto será avaliar a técnica InSAR como uma ferramenta para análises ambientais.

\section{Palavras-chave:}

Interferometria de radar, Garimpagem, Monitoramento do Impacto ambiental..

\section{Introdução}

A área das atividades garimpeiras estudadas neste trabalho localizam-se no Município Peixoto de Azevedo situado ao norte do estado Mato Grosso. Em 1980 até início de 1990, a região era responsável por cerca de $10 \%$ de toda a produção nacional de ouro, longe do que era na década de 80 , ainda responde com uma parcela significativa na economia da região. As atividades garimpeiras estão geralmente associadas a graves problemas de sustentabilidade acarretando forte impacto ambiental sobre o território.

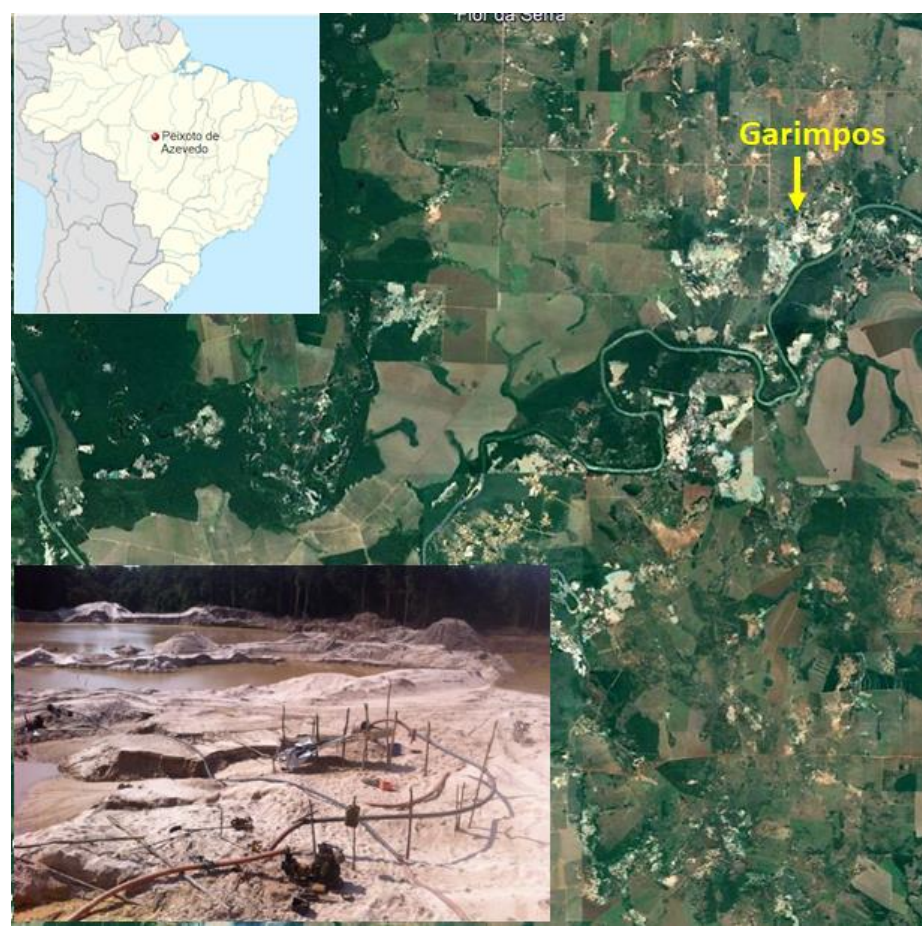

Figura 1. Mapa de localização da área de estudo próximo ao Município de Peixoto de Azevedo-MT. Imagem de satélite tomada do Google Earth (data de coleta: 7/3/2017). Foto da secção inferior esquerda tomada do site

\section{Resultados e Discussão}

Para fazer um diagnóstico atual das áreas já degradadas foi aplicada a técnica de interferometria por radar de abertura sintética (InSAR) que é a fusão da técnica de Radar de Abertura Sintética (SAR) com o modelo de interferometria. A interferometria é uma técnica que explora a informação da diferença de fase $(\Delta \Phi)$ entre duas ondas transmitidas pelo SAR orbital em tempos distintos (t1 e t2) por meio da diferença de fases, o InSAR consegue registrar movimentações e deformações do terreno como deslocamentos e subsidências (Bürgmann et al. 2000) ${ }^{1}$.

Foram utilizadas e processadas no software de código aberto da European Space Agency (ESA) SNAP imagens dos sensores radar Sentinel-1 e Alos/Palsar. Os mapas de deformação gerados possuem resolução insuficiente para delimitar com precisão as áreas de garimpo atuais.

\section{Conclusões}

$O$ auge das atividades garimpeiras em Peixoto Azevedo ocorreu na década de 90. As imagens de radar desse período mostraram resolução espacial e radiométrica insuficientes para gerar mapas de deformação precisos com a técnica InSAR. Imagens atuais possuem melhor resolução, no entanto como a deformação da área atualmente é menor, seria necessário melhorar a precisão da técnica InSAR utilizando trabalho de campo ou Interferometria SAR Diferencial Simples (DInSAR) para mapear deslocamentos superficiais.

\section{Agradecimentos}

Agradeço meu orientador Diego Ducart e ao incentivo à pesquisa pelo CNPq e oportunidade de ser bolsista de iniciação científica.

${ }^{1}$ Burgmann, R; Rosen, Paul A. ; Fielding, Eric J. . Synthetic aperture radar interferometry to measure earth's surface topography and its deformation. Annual Review of Earth and Planetary Sciences, [S.1 2000, 28, p. 169-209.

www.roteironoticias.com.br/2015/11/operacao-fecha- 